\title{
Vajinal Doğumda Ağrısının Azaltılmasına Yönelik Nonfarmakolojik Yöntemler ve Masajın Etkisi: 2000-2015 Yılları Tez Sonuçları
}

\section{Non-pharmacological Methods Used for Reducing to Pain in Vaginal Delivery and Effect of Massage: Thesis Results in 2000-2015}

\author{
Eliz TEKTAŞ ${ }^{a}$, Nalan AKAYa, Arife MAKa, Fatma AY ${ }^{\mathrm{b}}$
}

\begin{abstract}
ÖZET Giriş: Doğum eylemi, bilinen ve tanımlanan en şiddetli ağrı kaynaklarından biridir. Nonfarmakolojik ağrı kontrol yöntemlerinin doğumda anksiyete ve korkuyu azalttığı, ağrı kontrolünü arttırdığı ve konforu desteklediği bilinmektedir. Amaç: Vajinal doğumda ağrının azaltılmasın da ya da giderilmesinde vücudun farklı bölgelerine uygulanan masajın ağrı şiddeti üzerine etkilerini 2000-2015 yılları arasında yapılmış tez bulgularına göre irdelenmesi amacı ile yapılmıştır. Yöntem: Bu araştırma literatür incelemesi olarak yapıldı. "Türkiye Ulusal Tez Veri Tabanı"nda ilgili anahtar kelimeler kullanılarak 2000-2015 yılları arasında yapılmış yüksek lisans ve doktora tezleri tarandı. Araştırmanın dahil edilme kriterlerine uyan 6 tez araştırma yöntemleri, örneklem grupları, ağrı kontrol yöntemi, veri toplama araçları ve sonuçları açısından manuel olarak değerlendirildi. Bulgular: Tezlerin tümü hemşirelik alanında, \%50'si yüksek lisans ve \%50'si doktora programında, tümü deneysel / yarı deneysel tez olarak yapılmış çalışmalardır. Sıcak / soğuk uygulama ile masaj, Aromaterapi ve Ekspressif dokunma ile masaj ve refleksolojinin algılanan doğum ağrısını, kaygı ve anksiyete düzeyini azalttı̆̆ı, kadının ağrıyla baş edebilmesini ve kendine güvenini arttırdığı, doğumun süresini ise kısalttığı saptanmıştır. Sonuç: Araştırma kapsamına alınan tez sonuçlarına göre masajın doğum ağrısının kontrol edilmesinde kullanılabileceği saptanmıştır. Masaj doğum ağrısıyla başa çıkmada etkili bir girişimdir ve güvenle kullanılabilir. Öneriler: Araştırma sonuçları masajın doğum ağrıs1 algısı üzerine etkili olduğunu göstermesine rağmen bu alanda yapılmış araştırmaların ve tezlerin sayısı yetersizdir. Bu konuda yapılmıș ve yayınlanmıș araştırma sonuçları ile yüksek lisans / doktora tez sonuçlarının karşılaştırılması, sonuçların birleştirilmesi, uygulamanın yaygınlaştırılması ve araştırmanın yapıldı ğı klinik ile araştırma sonuçlarının paylaşılması önerilmektedir.
\end{abstract}

Anahtar Kelimeler: Ağrı, doğum ağrısı,vaginal doğum, nonfarmakolojik yöntemler, masaj.

ABSTRACT Backround: Childbirth is among the known most severe sources of pain. That is know that nonpharmacologic pain control methods decrease anxiety and fear, increase pain control and support comfort at birth. Purpose: The research was done in order to determine the affects of massage which is implemented at different parts of a body on pain level for reduction or elimination of labor pains according to the thesis's findings made in the years 2000-2015. Method: This research was done as cross-sectional and definitive. Master's and doctoral theses which were wrotten up at between 2000-2015 years were screened by using the relevant keywords in "Turkey National Thesis Database". The six thesis which are available for the criteria of researchs' inclusion were evaluated in terms of research methods, sample groups , pain control methods , data collection tools, results by manually. Findings: All of the theses are done on nursing field and $50 \%$ of them postgraduate thesis and $50 \%$ of them doctorate, and all of them are experimental/half-experimental thesis studies. Hot/cold application massage, aromatherapy and massage with expressive touching, reflexology are found to be decrease the percieved labor pain, stress and anxiety levels, increase the woman's pain threshold and trust. Also they decrease the delivery time. Result: According to reviewed theses, it is determined that massage can be used to preserve the perineal integrity and pain control. Massage is an efficient attempt to handle the labor pain and can be used safely. Recommendations: Although the results of the research on the perception of labor pain, the number of theses and studies in this field is not enough about that massage is effective. Comparing of results about published research with all Masters/PhD thesis on this subject, dissemination, implementation of the consolidation of results and research results must share with the clinic that is researches were made there is recommended.

Keywords: Pain, labor pain, vaginal birth, nonpharmacologic methods, massage.

\section{Giriş}

Ağrı tüm insanların yaşadığı, evrensel bir deneyimdir. ${ }^{1}$ Doğum ağrısı ise kadınların

Geliş Tarihi/Received: 06-06-2016/ Kabul Tarihi/Accepted: 11-12-2016

a İstanbul Üniversitesi Sağlık Bilimleri Fakültesi Ebelik Bölümü Öğrencisi

${ }^{\text {b } Y a r d . ~ D o c ̧ . ~ D r ., ~ I ̇ s t a n b u l ~ U ̈ n i v e r s i t e s i ~ S a g ̆ l ı k ~ B i l i m l e r i ~ F a k u ̈ l t e s i ~ E b e l i k ~ B o ̈ l u ̈ m u ̈ ~}$

Sorumlu yazar /correspondence: Yrd. Doç. Dr, Fatma Ay, İstanbul Üniversitesi Sağlık Bilimleri Fakültesi Ebelik Bölümü

* 3. Uluslararası \& 7. Ulusal Ebelik Öğrencileri Kongresi’nde sözel bildiri olarak sunulmuştur. 
olay olmasına rağmen kontrol altına alınması zordur. $^{2-7}$ Doğum ağrısının yönetimi, doğum sırasındaki anne bakımının asıl amaçlarından biridir. ${ }^{6}$ Doğum ağrısı anneyi yoran, oksijen gereksinimini arttıran, kan basıncının ve kardiyak out-put'un artmasına neden olan bir süreçtir. Fakat doğal bir süreç olması, belirli bir süre içinde gerçekleşmesi ve anneyi bebeğine kavuşturan mutlu doğası ile diğer ağrılardan farklıdır., ${ }^{2,4,8}$ Doğum ağrıs1 algıs1; doğum deneyimi, daha önce yaşanan ağrı deneyimi, ağrı ile baş etme yetenekleri, istenen gebelik / bebek olması, fizyolojik, psikolojik ve sosyokültürel faktörler vb. durumlardan etkilenmektedir. ${ }^{1,6}$ Yalnızlık hissi, geçmişte yaşanan ve çözümlenemeyen psikolojik sorunlar, kadının yaşadığ 1 stres ağrı şiddeti algısını etkilemektedir. Gebelerin doğum sürecinde yaşadığ 1 korku ve anksiyete pelvik kasların gerilmesine neden olmaktadır. Pelvik kaslarda oluşan gerilimin uzaması genel yorgunluğa, ağrının daha fazla hissedilmesine ve gebenin ağrı ile baş etme gücünün azalmasına neden olmaktadır. ${ }^{3}$ Doğum ağrısının kontrol altına alınması gebenin yaşadığı anksiyetenin azalmasını sağlayacaktır. ${ }^{3,6}$

Bakım vericiler ve kadınlar tarafindan doğum ağrısını azaltmanın basit yolu olarak tercih edilen farmakolojik olmayan birçok yöntem doğum ağrısını azaltmakla birlikte çok yaygın olarak kullanılmamaktadır. ${ }^{9}$ Giderek yaygınlaşan nonfarmakolojik ağrı kontrol yöntemleri, ilaç kullanılmadan tamamen kadının gevşemesine ve rahatlamasına yardımcı olan, ağrının en az algılanmasını sağlayan, yan etkisi olmayan, pozitif düşünmeyi sağlayan yöntemlerdir. 3,4,9 Nonfarmakolojik yöntemler doğumda rahatlamayı ve pozitif düşünmeyi desteklemek, ağrıyı ve acıyı azaltmak için önerilmektedir. ${ }^{4}$ Doğum ağrısını azaltmada kullanılan nonfarmakolojik yöntemlere müzik dinleme, akupunktur, acupressure, yoga, transkütanöz elektriksel sinir stimulasyonu (TENS), sicak ve soğuk uygulamalar, aromaterapi, masaj örnek verilebilir., ${ }^{1,4,5}$ Literatürde bu konuda yapılan araştırma sonuçları incelendiğinde; Brown ve arkadaşları doğumda kullanılan nonfarmakolojik ağrı kontrol yöntemlerini değerlendirdikleri çalışmada; müzik dinletilen annelerin \%30'unun, acupressure uygulanan annelerin \%42'sinin, sicak uygulama yapılan annelerin \%46'sinın, doğumda masaj ve efloraj uygulanan annelerin \%38'inin uygulamay1 çok etkili bulduğu; Ersanlı'nın araştırmasında müzik dinletilen annelerin \%60'nın müziği etkili veya kısmen etkili bulduğu; Burns ve arkadaşları 1990-1998 yılları arasında İngiltere'de gerçekleştirdikleri 8058 vakalı çalışmada, gebelerin \%50'sinden fazlasının doğumda aromaterapi kullanımını etkili bulduğu; doğumda akupunkturun etkinliği üzerine yapılan 3 randomize çalışmayı değerlendiren Lee ve Ernest'e göre akupunktur uygulanan deney gruplarında kontrol gruplarına kıyasla farmakolojik analjezi ihtiyacı oldukça düşük olduğu; Ülkemizde Mamuk tarafindan gerçekleştirilen 60 vakalı bir çalışmada, perineal sicak uygulama yapilan deney grubunun VAS puanlar1 kontrol grubuna kiyasla anlamlı derecede düşük olduğu belirtilmektedir. ${ }^{4}$

Doğum ağrısını azaltmada kullanılan en eski yöntemlerden biri masajdır. Masaj, sağlığı ve rahatlamayı arttırmak için vücudun belirli noktalarına sistematik amaçlı yapılan uygulamadır. ${ }^{3}$ Uygun şekilde yapılan masaj, yalnızca ağrı impulslarının bloke edilmesini sağlamakla kalmaz aynı zamanda kas spazmının ve gerginliğinin azalmasını da sağlar. Masaj, kolay yapılan bir uygulama olmakla birlikte ağrı duyusu üzerinde yüksek bir kontrol duygusu sağlamakta, ağrı duyusunu azaltmakta ve bireyin daha az ağrı yaşadığını düşünmesini sağlamaktadır. ${ }^{1}$ Masaj; ayak masaj1, sırt masaj1, boyun ve omuz masaj1 gibi farklı bölgelere uygulanabilir. ${ }^{10} 20$ dakika süre ile yapılan baş, boyun, sırt ve ayak masajının anksiyete ve ağrı düzeylerini azalttığ 1 , doğum eylemi süresinde kısalma sağladığı saptanmıştır. ${ }^{11}$ Masaj dolaşımı hızlandırarak kas spazmını çözmekte, kasları gevşetmekte ve rahatlama sağlamaktadır. Böylece doğum ağrısında, doğum sürecinin herhangi bir aşamasında yapılan masajın olumlu etki yarattığ1, ağrıyı azalttı̆̆g görülmüştür., ${ }^{9,12}$

Bu çalışma doğum ağrının azaltılması ya da giderilmesinde vücudun farklı bölgelerine uygulanan masajın ağrı şiddeti üzerine etkilerini belirlemek amacı ile literatür taraması olarak yapild.

\section{Yöntem}

“Türkiye Ulusal Tez Veri Tabanı"nda ilgili anahtar kelimeler kullanılarak 2000-2015 y1lları arasında yapılmış yüksek lisans ve doktora tezleri tarandı. Bu yıllar arasında doğum ile ilgili toplam 5183 teze ulaşıldı. Tarama "Doğum Ağrısı, nonfarmakolojik yöntemler, masaj” anahtar kelimeleri birlikte kullanılarak yapıldığında konu dışında kalan 5145 tez kapsam dışında bırakıldı. "Doğum Ağrısı, nonfarmakolojik yöntemler" anahtar kelimeleri ile veri tabanında tekrar tarama yapılarak, örneklem sayısı kontrol edildi. 


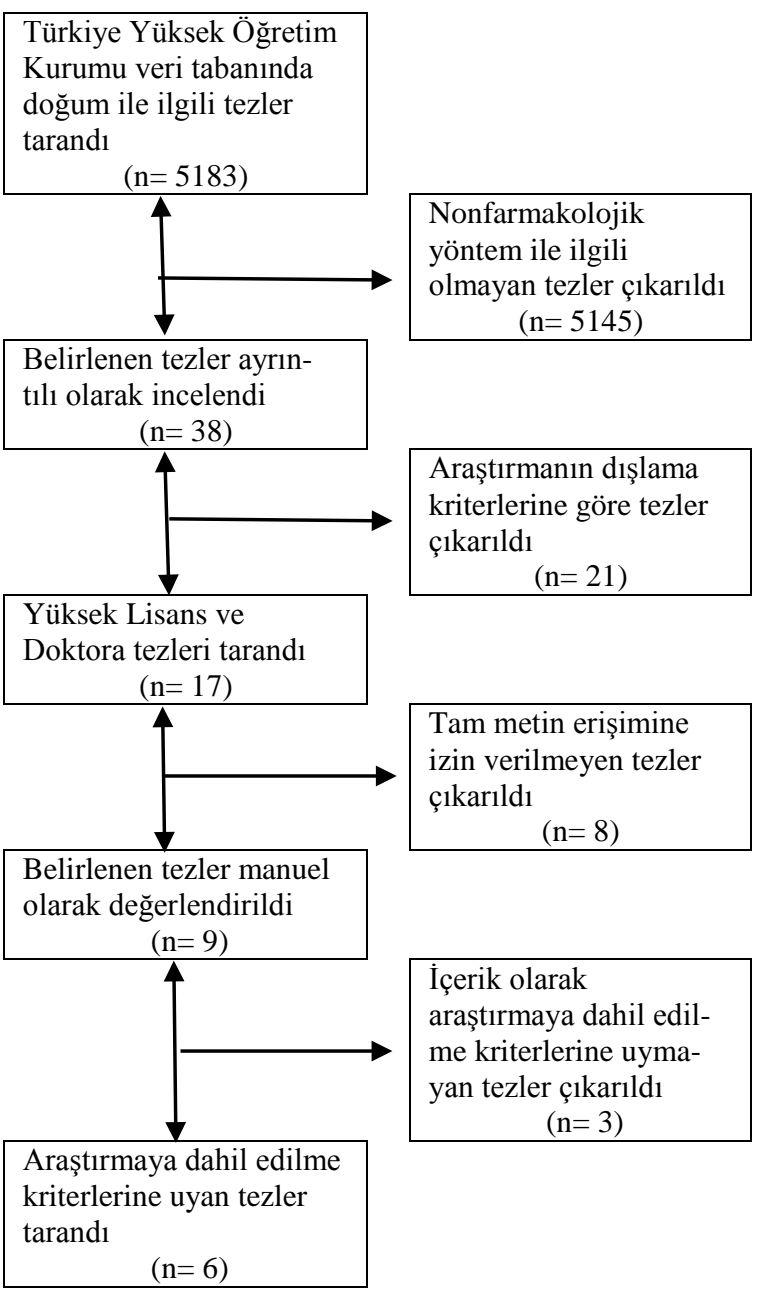

Şekil 1: Araştırmanın örneklem seçim akış şeması

Böylece toplam 38 teze ulaşıldı. 21 tez araştırmanın dahil edilme kriterlerine uymadığ 1 için araştırmadan çıkarıldı. 17 tez arasında araştırmacı tarafından tam metin erişimine izin verilmeyen 8 tez araştırmadan çıkarıldı. İncelenen 9 tez manuel tarama ile araştırma dışlama kriterleri açısından tekrar değerlendirildi ve 3 tez kapsam dışında bırakıldı. Bu evren içinde araştırma konusu ile uyumlu, erişimine izin verilen ve araştırma kriterlerine uygun olan 6 tez araştırmanın örneklemini oluşturdu. İncelenen tezler dahil edilme ve dişlama kriterlerine göre araştırma kapsamına alınmıştır (Şekil 1). Araştırmaya dahil edilme kiriterleri aşağıda belirtilmiştir. Bunlar;

- 2000-2015 yılları arasında yapılmış olan tezler,

- Vajinal doğum eylemi ile ilgili olan tezler,

- Masajın doğum ağrısı üzerine olan etkileri inceleyen tezler,

- Miadında doğum ve doğum ağrısı ile ilgili yapılan tezler,
- YÖK Tez Tarama veri tabanında tam metin erişimine izin verilen tezler,

Araştırmanın dışlama kriterleri aşağıda belirtilmiştir. Bunlar;

- Sezaryan doğum ile ilgili olan tezler,

- Doğum yapılan fiziksel ortam ile ilgili tezler,

- Farmakolojik yöntem etkinliğinin araştırıldığ tezler,

- Gebelerin öz yeterliliği ile ilgili tezler,

- Erken doğum eylemi ile ilgili yapılmış tezler,

Örneklem ve Değerlendirme: Oluşturulan evren içinde araştırmaya dahil edilme ve dişlama kriterleri kullanılarak örnekleme ulaşıldı. Tarama 02-29 Şubat 2016 tarihleri arasında "Türkiye Ulusal Tez Veri Tabanı" dan yapılan arama ile elde edildi. Araştırma kapsamına alınan 6 tez veri tabanına kayıt yılları, bilim dalları, örnek grubu, araştırma türü ve amac1, ağrı değerlendirme yöntemleri ve araştırma sonuçları açısından manuel olarak değerlendirildi.

\section{Bulgular}

Araştırma kapsamına alınan tezlerin tümü ilgili üniversitelerin Sağlı Bilimleri Enstitüleri Yüksek Lisans ve Doktora programları kapsamında Kadın Sağlığı ve Hastalıkları Anabilim Dalları'nda yapılmıştır. Tezlerin tümü araştırmacı tarafından uygulanmış, deneysel/ yarı deneysel tez olarak yapılmış çalışmalardır. Tezlerin 5'inde ağrı değerlendirme aracı olarak VAS, bir tezde VAS ile birlikte MASF, bir tezde VAS ile birlikte "Durumluluk Kaygı Ölçeği", ve bir tezde VAS ile birlikte "Normal Doğumda Anne Memnuniyetini Değerlendirme Ölçeği" kullanılmıştır (Tablo 1).

Tezlerin üçünde sıcak/soğuk masaj, birer tezde ise aromaterapi, refleksoloji ve ekspressif dokunmanın ağrı üzerine etkisi araştırılmıştır. İki tezin araştırma sonuçlarına göre sıcak uygulama ile birlikte masajın doğum ağrısı algısını azalttığı, iki tezde sicak uygulama ile masaj uygulanmasının ve aromaterapinin ağrı algısını azaltmakla birlikte doğumun süresini ise kısalttı̆̆ 1 saptanmıştır (Tablo 1). Yalnızca bir tezde LI4 noktasina yapılan buz masaj1 uygulamasının doğum ağrısı algısını azaltmada etkili olmadığı belirlenmiştir (Tablo 1).

\section{Tartışma}

Kadınların vajinal doğum yerine sezaryen doğumu tercih etme nedenlerinden biri doğum ağrısıdır. ${ }^{13}$ Sezaryen doğumun psikososyal 
Tablo 1.Tezlere ait bulgular

\begin{tabular}{|c|c|c|c|}
\hline Yazar, Y11, Tez No & Örneklem Grubu & Ağr1 Kontrol Yöntemi & Veri Toplama Araçları \\
\hline $\begin{array}{l}\text { Rojjin Mamuk } \\
2008 \\
\text { Tez No: } 204115\end{array}$ & $\begin{array}{l}\text { - } 60 \text { Gebe } \\
\text { - Deney grubu } 30 \\
\text { - Kontrol grubu } 30\end{array}$ & -Sicak uygulama & -Doğum İzlem Formu \\
\hline $\begin{array}{l}\text { Hafize Öztürk } \\
\text { 2006, } \\
\text { Tez No: } 193413\end{array}$ & $\begin{array}{l}\text { - } 50 \text { gebe kontrol grubu } \\
\text { - } 50 \text { Gebe Silikon } \\
\text { Uygulama Grubu } \\
\text { - } 50 \text { Gebe Buz }\end{array}$ & -Buz Masaj1 & $\begin{array}{l}\text {-Gebe Tanıtım Formu } \\
\text {-Doğum Eylemine İlişkin } \\
\text { İzlem Formu } \\
\text {-VAS* } \\
\text {-MASF** }\end{array}$ \\
\hline $\begin{array}{l}\text { Zümrüt Y1lar } \\
\text { 2014, } \\
\text { Tez No:379388 }\end{array}$ & $\begin{array}{l}\text { Uygulama Grubu } \\
\text { - } 64 \text { deney grubu } \\
\text { - } 64 \text { kontrol grubu }\end{array}$ & - Refleksoloji & $\begin{array}{l}\text {-Gebe tanitım formu } \\
\text {-VAS } \\
\text {-Partograf }\end{array}$ \\
\hline $\begin{array}{l}\text { Ayşenur İpek } \\
\text { 2014, } \\
\text { Tez No:379386 }\end{array}$ & $\begin{array}{l}\text { - } 40 \text { gebeye sicak } \\
\text { uygulama } \\
\text { - } 40 \text { gebeye masaj } \\
\text { uygulama } \\
\text { - } 40 \text { gebe kontrol grubu }\end{array}$ & $\begin{array}{l}\text { - Masaj } \\
\text {-Sicak uygulama }\end{array}$ & $\begin{array}{l}\text { - Gebe Tanıtım Formu } \\
\text {-Doğum Eylemine İlişkin } \\
\text { İzlem Formu } \\
\text {-VAS }\end{array}$ \\
\hline $\begin{array}{l}\text { Rabiye Erenoğlu } \\
\text { 2013, } \\
\text { Tez No:339502 }\end{array}$ & $\begin{array}{l}\text { - } 40 \text { deney grubu } \\
\text { - } 40 \text { kontrol grubu }\end{array}$ & -Ekspressif dokunma & $\begin{array}{l}\text {-VAS* } \\
\text {-Normal Doğumda Anne } \\
\text { Memnuniyetini } \\
\text { Değerlendirme Ölçeği }\end{array}$ \\
\hline $\begin{array}{l}\text { Hacer Karabulut } \\
\text { 2014, } \\
\text { Tez No:360078 }\end{array}$ & $\begin{array}{l}\text { - } 30 \text { kontrol grubu } \\
\text { - } 30 \text { deney grubu }\end{array}$ & -Aromaterapi & $\begin{array}{l}\text {-Tanıtıcı bilgi formu } \\
\text {-İnnatal dönem gözlem } \\
\text { formu } \\
\text {-Doğum sonu görüşme } \\
\text { formu } \\
\text {-VAS* } \\
\text {-Durumluluk Kaygı } \\
\text { Ölçeği }\end{array}$ \\
\hline
\end{tabular}

\section{Araştırma Sonucu}

Sıcak uygulamanın ağrıyı azalttığı, perineyi 3. ve 4. travmalara karşı korumada etkili olduğu, ayrıca anne konforunu olumlu yönde etkilediği belirlenmiştir. Sıcak uygulamanın perine bütünlüğünü korunmasında ve doğum ağrısının kontrol edilmesinde kullanılabileceği saptanmıştır.

LI4 noktasına yapılan buz uygulamasının doğum ağrı algısını azaltmada etkisi olmadığı belirlenmiştir. Ancak gebeler yapılan uygulamanın ağrılarını azalttı̆̆ını / hafiflettiğini sözel olarak belirtmişlerdir.

Ayak refleksolojisinin doğum ağrısını azaltmaya ve doğum eyleminin II. evresinin süresini kısaltmaya olumlu etkisinin olduğu belirlenmiş̧ir. Bu sonuç doğrultusunda doğum eyleminde yaygın olarak ayak refleksolojisinin kullanılması önerilmiştir.

Derisel terapi yöntemlerinin (masaj ve sıcak uygulama) doğumun aktif faz süresini kısalttı̆̆ı, doğumun aktif ve geçiş fazlarındaki ağrı algısını azalttığı bulunmustur. Bu sonuçlar masaj ve sicak uygulamanın doğum ağrısıyla başa çıkmada etkili bir hemşirelik girişimi olduğunu ve güvenle kullanılabileceğini göstermektedir.

Doğumda uygulanan ekspressif dokunmanın; ağrı duyusu üzerinde olumlu etkileri olduğu ve doğum ağrısını azalttığı, anne memnuniyet düzeyini arttırdığı saptanmıştır.

Doğumda uygulanan aromaterapinin kadının doğum ağrısını algılamasını, kaygı ve anksiyete düzeyini azalttığı, kadının ağrıya tahammülünü ve güvenini arttırdığı, doğumun süresini ise kısalttığı saptanmıştır. Bunun yanında aromaterapi uygulaması ile ilgili hiçbir maternal ve fetal yan etki ise görülmediği belirlenmiştir. 
nedenleri arasında negatif doğum eylemi ve doğum ağrısından korku olduğu belirtilmektedir. Doğum ağrısının şiddetlenmesi ile birlikte kadınların doğum sürecine ilişkin korkusu artmakta, gebe korktukça gerilmekte ve anksiyete seviyesi artmakta, anksiyete seviyesi artıkça daha fazla ağrı hissetmektedir. ${ }^{3}$ Ağrıyı azaltıc1 nonfarmakolojik yöntemlerin ebe ve hemşireler tarafindan doğum eylemindeki kadınlara öğretilmesi ve uygulatılması kadınların korku ve gerilimlerini azaltabilir. ${ }^{14}$ Şahin ve ark.'nın yaptığı bir araştırmada kadınların \%58'ine doğum ağrısı ile baş etmek için hiçbir şey yapılmadığı, diğerlerine ise sadece öğrenci ebe ve hemşireler tarafindan solunum egzersizleri ve masaj gibi nonfarmakolojik girişimlerin yapıldı ğ 1 bildirilmiştir. ${ }^{13}$ İncelenen tez sonuçlarına dayanarak gebelerin doğum korkusu ile başetmesine yardımcı olan, maliyeti düşük, yan etkisi olmayan, öğretilmesi ve uygulanması kolay olan masajın araştırma kapsamında araştırmacı tarafindan uygulandığı, hemşeri / ebe tarafindan yapılan yaygın bir uygulama olmadığı söylenebilir.

Masaj doğum sırasında kullanılan yaygın bir tekniktir. ${ }^{15}$ Masajla beta endorfin salınımı artar, derideki dokunma reseptörleri uyarılarak ağrının dar bir alanda lokalize olması sağlanır, ağr1 eşiği yükseldiği için ağrı sinyalinin beyine iletimi engellenmiş olur. ${ }^{12,15}$ " $3-5$ cm'lik servikal dilatasyon sırasında 20 dakika süreyle yapılan bel, boyun, sirt ve ayak masajının anksiyete, endişe ve ağn düzeylerinde belirgin derecede düşüş, doğum eylemi sürecinde kısalma gibipozitif etkileri olduğu yönünde yöntemi destekleyici çalışmalar bulunmaktadır". ${ }^{11}$ Chan ve Ark.'nın araştırmalarında deney grubu kadınlara uygulanan masajın doğumun aktif, latent ve geçiş fazında istatistiksel açıdan anlamlı olarak ağrıyı azalttığını saptamıştır. Ayrıca deney grubunun \%87'si doğum süreci boyunda masajın yararl1, ağrıyı azaltan ve psikolojik destek sağlayan bir uygulama olduğunu belirtmiştir. ${ }^{15}$ Simkin ve O'Hara'nın yaptığ araştırmada incelenen üç araştırmada kadınların çoğu masajın doğum süreci ile başetmeye yardım ettiğini, ağrıyı kolaylaştırdığını, kendilerini iyi hissetmeye yardım ettiğini ve cesaretlendirdiğini belirtmiştir. ${ }^{9}$ Simkin ve Boldig ise araştırmalarında masajın kadınların kontrol duygusunu arttırdığını, duygu durumlarını pozitif yönde değiştirdiğini, dikkati ağrıdan uzaklaştırdığını ve ağrı şiddeti algısını azalttığını saptayan çalışma bulguları saptamıştır. ${ }^{16}$ Araştırma kapsamına alınan tezlerin tümünde sıcak / soğuk uygulama, refleksoloji, aromaterapi gibi tekniklerle birlikte masaj uygulaması yapılmış ve literatürle paralel olarak olumlu sonuç elde edilmiştir.

Teorik olarak sicak uygulama kas spazmını gidererek kas gerginliğini azaltır, dokuların viskoelastik özelliklerinde değişmeye neden olarak sinir uçlarındaki baskı ve gerilme gibi etkileri azaltıp analjezi sağlar. Diğer yandan vazodilatasyon ile kanın vizkozitesinin azalması, kan dolaşımın artması, ağrı impulslarını stimüle eden hücre metabolitlerinin eliminasyonunu sağlar. İskemi sonucu gelişen gerilim tipi ağrıda da bölgenin kanlanmasını sağlayarak analjezik etki yaratır ve 1sı reseptörleri aracılığı ile ağrıyı inhibe eden refleksleri harekete geçirir., ${ }^{1,4,17}$ Yüzeyel sıcak uygulama vajinal doğumun birinci evresinde bel ağrılarını rahatlatmak, doğumun ikinci evresinde ise perine ağrısını azaltmak ve perineyi travmalara karşı korumak amacıyla kullanılır. ${ }^{4,16}$ Perineal sicak uygulama bebek başının inişi sırasında yaşanan perineal ağrıyı azaltmaktadır.,17 Dahlen ve arkadaşlarının gerçekleştirdiği 717 vakalı randomize çalışmada; perineal sicak uygulama yapılan deney grubunun VAS puanları anlamlı derecede düşük bulunmuş, annelerin uygulamanın perine ağrılarını azalttığını belirttikleri bildirilmiştir. ${ }^{17}$ Brown ve arkadaşlarının araştırmasında doğumda sıcak uygulama yapilan annelerin \%46'sinin uygulamayı çok etkili bulduğu bildirilmiştir. ${ }^{4}$ Araştırma kapsamına alınan ve Mamuk tarafindan gerçekleştirilen 60 vakalı çalışmada, perineal sicak uygulama yapilan deney grubunun VAS puanları kontrol grubuna kiyasla anlamlı derecede düşük bulunmuştur. Aynı çalışmada annelerin tamamına yakınının perineal sicak uygulamayı sevdiği ve bir daha ki doğumlarında da kullanmak istedikleri bildirilmiştir. ${ }^{18}$ Araştırma kapsamına alınan diğer tez çalışmasında ise derisel terapi yöntemlerinin (masaj ve sicak uygulama) doğumun aktif faz süresini kısalttığı, doğumun aktif ve geçiş fazlarındaki ağrı algısını azalttığ 1 bulunmuştur. ${ }^{19}$

Soğuk uygulama kas spazmını ve ödemi azaltır, kalın çaplı sinir liflerinin stimülasyonu ile derinin duyarlılığını azaltarak, ağrının hafif hissedilmesini sağlar. ${ }^{5}$ Aktif fazda LI4 bölgesine uygulanan buz masajı doğum ağrısını hafifletmektedir. ${ }^{8}$ Soğuk uygulamanın doğum ağrıs1 üzerine etkisini belirlemek amaciyla yapılan bir çalışmada, doğum eylemi sırasında, LI4 noktasına buz masajı uygulanmış ve kadınların ağrı algılama puanlarında düşüş 
olduğu ve bu uygulamanın ağrı algısını azalttığı belirlenmiştir. ${ }^{20}$ Öztürk'ün (2006) doğum eyleminde LI4 enerji meridyen noktasina uygulanan buz masajının doğum ağrısı algısı üzerine etkisini belirlemek için yaptığı tez çalışmasında, buz veya silikon uygulamasının travay süresine etkisine bakılmış, buz uygulamasının doğum ağrı algısı puanlarını azaltmada etkisinin olmadığı, ancak kadınların yapılan uygulamanın ağrılarını azalt-tığını/hafiflettiğini ifade ettikleri saptanmiştır. ${ }^{21}$

Aromaterapi topikal (masaj), aromatik (inhalasyon, banyo) ve dahili (oral preparat, bitki çayı, sıv1 şekilde oral) olarak üç şekilde uygulanabilir. Doğum sirasında en yaygın uygulanan aromaterapi yöntemleri masaj, banyo ve inhalasyondur. ${ }^{22}$ Aromaterapide genellikle yağlar masajın terapötik etkisiyle birleştirilmektedir. ${ }^{4}$ Burns ve arkadaşları 1990-1998 yılları arasında İngiltere'de gerçek-leştirdikleri 8058 vakalı çalışmada, gebelerin \%50'sinden fazlasının doğumda aromaterapi kullanımını etkili, \%14'ünün ise etkisiz bul-duğunu bildirmiştir. ${ }^{16}$ Araştırma kapsamına alınan Karabulut'un (2014) tez çalışmasında kontrol ve deney grubu arasinda, latent fazda değerlendirilen VAS ortalama puanları yönünden anlamlı bir fark saptanmamakla birlikte, aromaterapi uygulanan gruptaki kadınların, kontrol grubundaki kadınlara göre aktif ve geçiş fazında doğum ağrısını daha az algıladıkları bulunmuştur. ${ }^{22}$

Chung ve ark.' 'nın (2003) akupresür ve eflorajın doğum ağrısına ve uterus kontraksiyonlarına olan etkisinin incelendiği bir çalışmada, doğumun latent fazında deney ve kontrol grupları arasında anlamlı bir fark bulunmamıştır. Ancak aktif fazındaki akupresür ve kontrol arasında VAS değerlerinde anlamlı farkl11ık olduğu bulunmuştur. ${ }^{7}$ Erenoğlu'unun (2013) araştırma-sında deney grubunda doğumda uygulanan ekspressif dokunmanın doğum ağrısını azalttığı saptanmıştır. ${ }^{23}$

Ayak masajı ile birçok refleks noktası uyarılır ve doğum eyleminin daha kolay geçmesine yardımc1 olur. ${ }^{10}$ Randomize bir çalışmada, doğum sırasında 5 saat boyunca, kadınlara her 20 dakikada bir partnerleri tarafından ayak, sırt, el ve baş masajı yapılmış ve sık masajın kadınların ağrısını ve anksiyetesini azaltıp duygusal durumunu daha da iyileştirdiği belirlenmiştir. ${ }^{6}$ Araştırmamız kapsamına alınan Yıllar'ın (2014) tez çalışmasında da ayak refleksolojisinin doğum ağrısını azaltmaya ve doğum eyleminin II. evresinin süresini kısaltmaya olumlu etkisinin olduğu belirlenmiştir. $^{24}$

\section{Sonuç ve öneriler}

Nonfarmakolojik ağrı kontrol yöntemlerine ilişkin kanıt düzeyi yüksek çalışmaların sayısı oldukça azdır. Ancak tüm çalışmaların ortak sonucu, nonfarmakolojik yöntemlerin gebelerin doğum korkusu ile başetmelerine yardımcı olduğu, annelerin rahatlamalarını sağladığı, böylece ağr1 algısını azalttığı yönündedir. İncelenen tüm tez sonuçları masaj, sıcak / soğuk uygulama, aromaterapi, refleksoloji ve ekspressif dokunmanın doğum ağrısıyla başa çıkmada etkili bir girişim olduğunu ve güvenle kullanılabileceğini göstermektedir. Ayrıca bu uygulamaların anne memnuniyet düzeyini arttırdığ 1 saptanmıştır.

Temel amacı anneyi fiziksel ve psikolojik açıdan desteklemek olan ve hiçbir yan etkisi olmayan masajın daha yaygın olarak kullanılması için bu konu ile ilgili araştırmaların yapılması ve sonuçlarının yaygınlaştırılması önerilmektedir. Ayrıca doğumhanede çalışan ebe ve hemşireler ile masajın doğum ağrisı üzerine etkisini araştıran çalışmaların yapılması non invaziv yöntemlerin yaygınlaşmasını sağlayacağı için bu grupla araştırmaların yapılması, araştırma sonuçlarının kurum yönetimi ile paylaşılması önerilmektedir. Her bireyin ağrı şiddeti algısı ve yapılan uygulamalara tepkisi farklıdır, kültürel yapıdan ve bireysel faktörlerden etkilenir. $\mathrm{Bu}$ nedenle gebelerde masajın ağrı şiddeti algısı üzerine etkisi araştırllırken sosyodemografik özelliklerin ilişkisini araştıran çalışmaların yapılması yararlı olacaktır. Ayrıca nonfarmakolojik yöntemlerden en yaygın ve uygulanmas1 basit olan masajın doğum ağris1 yönetiminde kullanılması ile doğum ağrıs1 korkusu yüzünden sezeryan doğum tercihlerinin azalacağı tahmin edilmektedir.

\section{Kaynakça}

1- Tel H. (2015). Ağr1, ağriya yönelik uygulamalar ve hasta bakımı. Sabuncu N, Akça Ay F, Editörler. Klinik Beceriler: Sağlığın Değerlendirilmesi, Hasta Bakım ve Takibi, Nobel Tip Kitabevleri, İstanbul, 651-674.

2- Karabulutlu Ö. Doğum ağrısında kullanılan nonfarmakolojik yöntemler. Caucasion Journal of Science 2014; 1(1): 43-50.

3- Gönenç İM, Terzioğlu F. Doğum ağrıs1 yönetiminde kullanılan masaj ve akupressürün gebelerin anksiyete üzerine etkisi. ASB Dergisi 2012; 1(3): 129-143. 
4- Mamuk R, Davas Nİ. Doğum ağrısının kontrolünde kullanılan nonfarmakolojik gevşeme ve tensel uyarılma yöntemleri. Şişli Etfal Hastanesi Tıp Bülteni 2010: 44(3); 137-142.

5- Mucuk S, Başer M. Doğum ağrısını hafifletmede kullanilan tensel uyarılma yöntemleri. Journal of Anatolia Nursing and Health Sciences 2009; 12(3): 61-66.

6- Taşçı E, Sevil Ü. Doğum ağrısında nonfarmakolojik yöntemler. Genel Tip Dergisi 2007; 17(3): 181-186.

7- Chung UL, Hung LC, Kuo SC, Huang CL. Effects of LI4 and BL 67 acupressure on labor pain and uterine contractions in the first stage of labor. JNR 2003; 11(4): 251- 260.

8- Öztürk Can H, Saruhan A. Gebelerde algılanan doğum ağrısının azaltılmasında ele uygulanan buz masajının etkisi. HEMARGE 2008; 19(1):18-37.

9- Simkin P, O’Hara M. Nonpharmacologic relief of pain during labor systematic reviews of five methods. Am J Obstet Gynecol. 2002; 186: 131-159.

10- Yıldırım G, Şahin NH. Doğum ağrısının kontrolünde hemşirelik yaklaşımı. C. $\ddot{U}$. Hemşirelik Yüksek Okulu Dergisi 2003; 7 (1): 1420.

11- Avcibay B, Alan S. Doğum ağrıs1 kontrolünde nonfarmakolojik yöntemler. Mersin Üniversitesi Sağlık Bilimleri Dergisi 2011; 4(3): 18-24.

12- Özveren H. (2011). Ağr1 kontrolünde farmakolojik olmayan yöntemler. Hacettepe Üniversitesi Sağllk Bilimleri Fakültesi Hemşirelik Dergisi 2011; 18(1): 83-92.

13- Şahin N, Dinç H, Dişsiz M. Gebelerin doğuma ilişkin korkuları ve etkileyen faktörler. Zeynep Kamil Tıp Bülteni 2009; 40(2): 57-62.

14- Karaçam Z. Akyüz E.Ö. Doğum eyleminde verilen destekleyici bakım ve ebe/hemşirenin rolü. Florence Nightingale Hemşirelik Dergisi 2011; 19(1): 45-53.

15- Chang M.Y, Wang S.Y, Chen C.H. Effects of massage on pain and anxiety during labour: a randomized controlled trial in Taiwan. JAN 2002; 38(1), 68-73.

16- Simkin P, Boldig A. Update on nonpharmacologic approaches to relieve labor pain and prevent suffering. J Midwifery Womens Health 2004; 49(6): 489-504.

17- Dahlen HG, Homer CSE, Cooke M, Upton AM, Nunn RA, Brodrick BS. Soothing the ring of fire': Australian women's and midwives' experiences of using perineal warm packs in the second stage of labour. Midwifery 2009; 25: 3948.

18- Mamuk R. Vajinal doğumun ikinci aşamasında perineye sıcak uygulama yapmanın perine bütünlüğüne ve ağriya etkisi [Effect of heat application to the perineum in normal vaginal deliveries on perineal integrity and pain]. [Yüksek Lisans Tezi] Marmara Üniversitesi Sağlık Bilimleri Enstitüsü, Kadın Sağlığı Hemşireliği Anabilim Dalı, İstanbul, Türkiye, 2008.

19- İpek A. (2014). Doğum eyleminde alt sırt bölgesine uygulanan derisel terapi yöntemlerinin doğum ağrısı algısına ve doğumun süresine etkisi [The effects of the application of topical therapy methods to inferior dorsal side in labor action on labor pain perception and time of delivery]. [Yüksek Lisans Tezi] T.C. Ankara Üniversitesi Sağlık Bilimleri Enstitüsü, Doğum, Kadın Sağlığı ve Hastalıkları Hemşireliği Anabilim Dalı, Erzurum, Türkiye, 2002.

20- Waters BL, Raisler J. Ice massage for the reduction of labor pain. JMWH 2003; 48 (5): 317321.

21- Öztürk H. Gebelerde algılanan doğum ağrısının azaltılmasında ele uygulanan buz masaj1 etkisinin incelenmesi [Studyıng the affect of ice-massage applied to hands of pregnant women to reduce the perceived labor pains]. [Doktora Tezi] T.C. Ege Üniversitesi Sağlık Bilimleri Enstitüsü, Doğum ve Kadın Sağlığ Hastalıkları Hemşireliği Anabilim Dalı, İzmir, Türkiye, 2006.

22- Karabulut H. Doğum eyleminde aromaterapinin etkileri [The effects of aromatherapy in labor]. T.C. İstanbul Üniversitesi Sağl1k Bilimleri Enstitüsü Kadın Sağlığı Ve Hastalıkları Hemşireliği Anabilim Dal1, İstanbul, Türkiye, 2014.

23- Erenoğlu R. Ekspressif dokunmanın doğum ağrıs1 ve anne memnuniyetine etkisi [Effect of expressive touching on labour pain and maternal satısfaction]. [Doktora Tezi], T.C. Erciyes Üniversitesi Sağlık Bilimleri Enstitüsü, DoğumKadın Sağlığı Ve Hastalıkları Hemşireliği Anabilim Dalı, Kayseri, Türkiye, 2013.

24- Yillar Z. Ayak refleksolojisinin doğum ağrısına ve doğum eyleminin süresine etkisi [The Effect of Foot Reflexology on the Time of Labor Pain of Childbirth]. [Yüksek Lisans Tezi], T.C. Ankara Üniversitesi Sağlık Bilimleri Enstitüsü, Doğum, Kadın Sağlığı ve Hastalıkları Hemşireliği Anabilim Dalı, Erzurum, Türkiye, 2014. 